\title{
Issues and Challenges in the Nigerian Electricity Industry: Case of Benin Electricity Distribution Company
}

\author{
Roland Uhunmwagho
}

Kenneth E. Okedu

Department of Electrical Engineering

University of Port Harcourt, Nigeria

Doi:10.5901/ajis.2013.v2n12p153

\begin{abstract}
Benin Electricity Distribution Company covers four states, viz: Edo, Delta, Ondo and Ekiti with its headquarters in Benin City. It presently has eighteen districts. This paper addresses and proffers solutions to some of the major issues and challenges in the Nigerian electricity industry considering the Benin electricity distribution company in the South West zone of Nigeria. The status of transmission, distribution and commercial activities in this zone were analyzed. Recommendations were made to improve or focus on the remedies which would help solve the erratic power supply in the region in particular, and in the country in general, if these measures could be extended to other geopolitical electricity companies.
\end{abstract}

Keywords: Nigerian electricity, distribution, transmission, network and substation

\section{Introduction}

Due to population growth and subsequent increased demand for higher efficiency and reliable electricity supply, power systems are being forced to operate at almost full capacity (Happ. H., 1994, and Illic M. et al, 1997). The electric utility industry is probably the largest and the most complex in the world (Silva E. Mesa, et al, 1998 and Park Y., et al, 1998). The complexity of a power system is directly proportional to the number of buses which it serves.

In Nigeria, the electricity industry is in the process of deregulation and it is proposed that the old National Electric Power Authority (NEPA) now Power Holding Company of Nigeria (PHCN) which had a whole responsibility of generation, transmission and distribution of electricity, would be unbundled into six generating companies, eleven distribution companies and just one transmission company (PHCN annual report, 2009-2010). These companies need to be result driven and profitable to the investors. Thus, each of them must be able to account for the amount of energy it draws or supplies to its clients.

This paper presents and proffers solutions to some of the issues and challenges in one of the distribution companies named Benin electricity Distribution Company in the South West zone of Nigeria. The Benin zone covers four states which are Edo, Delta, Ondo and Ekiti. Also, there are eighteen districts in this zone. The way forward to solving some of the highlighted major issues and challenges in this zone were also suggested.

\section{Benin Electricity Distribution Company (BEDC) Areas of Operation}

This paper is limited to issues and challenges in the BEDC as specified in the Nigerian map in Fig.1. Figure 1 shows the four states of operation in the zone which comprises eighteen districts. 


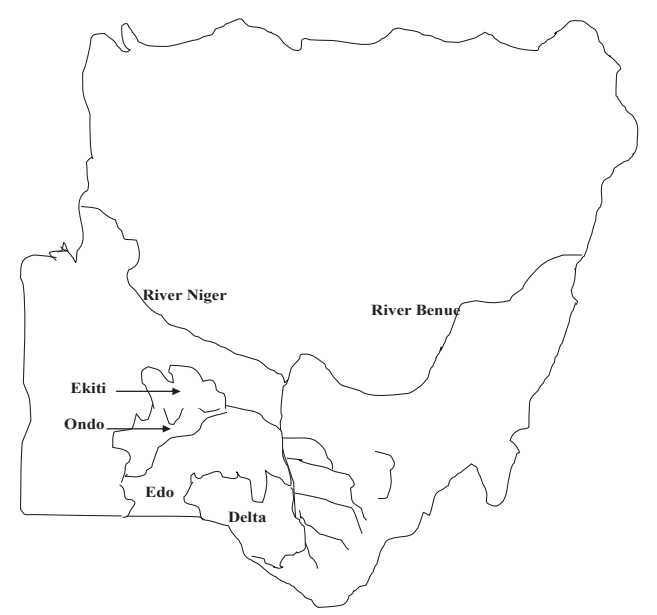

Fig.1: Nigerian map showing the BEDC areas of operation

\section{Supply in Feed into the Zone}

The supply in feed into the BEDC zone is shown in Table 1. From the table, it could be observe that there are twelve main supply-in feed.

Table 1: Supply in feed to BEDC

\begin{tabular}{|c|l|c|}
\hline 1 & Akure $132 / 33 \mathrm{kV}$ TS & 1×60MVA; $2 \times 30 \mathrm{MVA}$ \\
\hline 2 & Okene $132 / 33 \mathrm{kV}$ TS & $2 \times 30 \mathrm{MVA}$ \\
\hline 3 & Ondo $132 / 33 \mathrm{kV}$ TS & $2 \times 30 \mathrm{MVA}$ \\
\hline 4 & Omu-Aran $132 / 33 \mathrm{kV}$ TS & $2 \times 30 \mathrm{MVA}$ \\
\hline 5 & Ilesa $132 / 33 \mathrm{kV} \mathrm{TS}$ & $2 \times 30 \mathrm{MVA}$ \\
\hline 6 & Benin $132 / 33 \mathrm{kV}$ TS & $4 \times 60 \mathrm{MVA}$ \\
\hline 7 & Onitsha $132 / 33 \mathrm{kV}$ TS & $1 \times 30 \mathrm{MVA} ; 1 \times 60 \mathrm{MVA}$ \\
\hline 8 & Irrua $132 / 33 \mathrm{kV}$ TS & $1 \times 60 \mathrm{MVA} ; 1 \times 30 \mathrm{MVA}$ \\
\hline 9 & Okpella $132 / 33 \mathrm{kV}$ TS & $1 \times 15 \mathrm{MVA}$ \\
\hline 10 & Effurun $132 / 33 \mathrm{kV}$ TS & $2 \times 60 \mathrm{MVA} ; 1 \times 30 \mathrm{MVA}$ \\
\hline 11 & Delta $132 / 33 \mathrm{kV}$ TS & $1 \times 60 \mathrm{MVA} ; 1 \times 30 \mathrm{MVA}$ \\
\hline 12 & Amukpe $132 / 33 \mathrm{kV}$ TS & $1 \times 30 \mathrm{MVA}$ \\
\hline
\end{tabular}

\section{BEDC Network Data}

The total installed injection capacity is 1,255.31MVA, while the total installed distribution capacity is $1,564.4 \mathrm{MVA}$. The peak load demand is 560MW on the average load allocation of 403MW. The average monthly energy received from grid is $220 \mathrm{MWH}$ in the four states and eighteen districts.

\section{Status of Distribution Network and Commercial Activities}

The status of the distribution network and commercial activities are summarized in Table 2.

Table 2: Status of distribution network and commercial activities (PHCN, 2011) 


\begin{tabular}{|l|c|}
\hline Number of 33kV circuits & 47 \\
\hline Number of injection substation (comprising of PHCN owned and privately owned) & 175 \\
\hline Number of overloaded injection substation & 51 \\
\hline Length of 11kV feeder (km) & 6,840 \\
\hline Number of 11kV circuits & 253 \\
\hline Number of distribution transformers in circuit & 7,562 \\
\hline Number of overloaded distribution transformers & 1,183 \\
\hline Length of O.415kV line (km) & $49,683.21$ \\
\hline Length of undersized 11kV line (km) & 229 \\
\hline Length of undersized LT line (km) & 8,425 \\
\hline Energy billed (kwh) & $220,225,460$ \\
\hline Amount collected (in Naira) & $1.457 \mathrm{billion}$ \\
\hline Outstanding Debt (N); about N2.2n owned by Government Account & $13.458 \mathrm{billion}$ \\
\hline
\end{tabular}

\subsection{Customer Service}

There are 666, 584 connections in the zone and residential amounts to $88.67 \%$, consuming $73.19 \%$ of the energy billed. The commercial amounts to $10.36 \%$, consuming $15.21 \%$ of the energy billed, while the industrial activities in the area accounts for $0.69 \%$ thereby consuming $4.37 \%$ of the energy billed. Special customers may go up to $0.26 \%$, and consuming $6.82 \%$ of energy billed. However, $0.05 \%$ of the energy billed is for street lighting.

Therefore, the average monthly sales lumps to NGN 1.9B, while the average monthly revenue is NGN $1.4 \mathrm{M}$, with weighted average tariff of NGN $8.0 / \mathrm{kwh}$.

\section{Network Expansion and Revenue Improvement}

In the last few months there has been installation and commissioning of eight injection substations in the zone. Also, there has been installation of and commissioning of thirty eight distribution transformers of various ratings with combined capacity of 110 MVA as follows: Edo state is136, Delta state is152, ), Ondo state is 40 , while Ekiti state is 52.

The constructed network facilities are $36.3 \mathrm{~km}$ of $33 \mathrm{kV}$ overhead lines and $1.35 \mathrm{~km}$ of $33 \mathrm{kV}$ underground network, and $74.0 \mathrm{~km}$ of $11 \mathrm{kV}$ overhead and $12.2 \mathrm{~km}$ of $11 \mathrm{kV}$ underground network.

The number of metered customers grew from 212,216 in December 2010 to 449,294 in early this year. Hence the metering gap needs to be closed. The average monthly revenue moved from $\mathrm{N} \mathrm{1.023bn} \mathrm{in} 2010$ to a present value of N 1.45bn monthly by early this year. This is about $18.52 \%$ increase.

The average daily supply availability in hours recorded in the zone is given in Table 3.

Table 3: Average daily supply availability in the zone (PHCN, 2012)

\begin{tabular}{|l|c|c|}
\hline \multicolumn{1}{|c|}{ Areas } & 33kV feeders & 11kV feeders \\
\hline Uromi district & 19 & 18 \\
\hline Auchi district & 13 & 12 \\
\hline Benin GRA & 21 & 20 \\
\hline Ikpoba Hill & 19 & 17 \\
\hline Sakponba & 20 & 19 \\
\hline Ekenwa road axis & 19 & 18 \\
\hline Ugbowo & 16 & 14 \\
\hline Asaba district & 13 & 8 \\
\hline Agbor district & 12 & 8 \\
\hline Ughelli GRA & 19 & 18 \\
\hline Sapele & 20 & 19 \\
\hline
\end{tabular}




\begin{tabular}{|l|l|l|}
\hline Warri & 19 & 18 \\
\hline Effurun & 20 & 19 \\
\hline Akure district & 16 & 15 \\
\hline Ondo district & 19 & 18 \\
\hline Owo district & 18 & 17 \\
\hline Igbara-Oke & 15 & 14 \\
\hline Ado-Ekiti & 18 & 17 \\
\hline
\end{tabular}

\section{Issues and Challenges}

Some of the major issues and challenges in the distribution zone under study particular and the other distribution zones in the country are given as follows:

- $33 \mathrm{kV}$ line transverse difficult terrain is thick having mangrove vegetation; flooding and swampy areas with their peculiar line trace problems.

- Many 33kV feeders, 11kV feeders are fully loaded

- 1,183 number of distribution transformers and 51 number injection transformers are overloaded

- The metering gap that exists now is a big issue

- The present tariff structure does not make for efficient running of the distribution system

- Inability of customers to pay their electricity bills as at when due, particularly government institutions

- The issue of contract or casual staff is also there as they constitute a significant proportion of the workforce

- Vandalisation of PHCN equipment and lines

- Inadequate funding for the electricity business

- Asaba is the only state capital still on 33kV supply from Onitsha. The NIPP 132/33kV substation is very slow.

\subsection{Transmission Substation Challenges}

The following are the transmission challenges in the studied zone:

\subsubsection{Okpella 132/33kV TS}

The 15MVA $132 / 33 \mathrm{kV}$ transformer is grossly overloaded. The substation should be upgraded to 60MVA, 132/33kV TS

\subsubsection{Irrua 132/33kV TS:}

There is poor voltage profile at the tail end of $33 \mathrm{kV}$ feeders due to overloaded power transformers and long lines. Also, there is load limitation due to undersized conductor between Benin and Irrua. The 300MVA transformer at Irrua substation should be upgraded to a 60MVA to accommodate more loads. The undersized conductor between Benin and Irrua should be upgraded to improve power delivery to Irrua TS.

\subsubsection{Effurun 132/33kV TS:}

The substation was commissioned in the early $70 \mathrm{~s}$. Virtually all the $33 \mathrm{kV}$ switchgears and terminal equipments are now obsolete and cannot guarantee stable supply. This transmission substation requires major rehabilitation works and equipment upgrade. 


\subsubsection{Amukpe-Sapele 132/33kV TS:}

The 30MVA 132/33kV transformer is already overloaded. Additional 30MVA transformer is required for immediate installation.

\subsection{Transmission Substation Limitations}

\subsubsection{Akure 132/33kV TS:}

There are serious load limitations due to undersized conductor-on the $132 \mathrm{kV}$ line between Osogbo and Akure. Urgent upgrading/re-conducting of Osogbo-Akure $132 \mathrm{kV}$ lines required to reduce the protracted load shedding in Akure.

\subsubsection{Ondo 132/33kV TS:}

The 33kV Siemens indoor feeder breakers at Ondo TS are obsolete and in a state of disrepair. This requires immediate replacement.

Owo is fast city in Ondo state. The receiving end voltage here is low due to the absence of TS. A 60MVA, 132/33kV TS should be constructed in Owo.

\section{Conclusions and Recommendations}

The major issues and challenges in the Benin Electricity Distribution Company (BEDC) comprising two states in the Nigeria south-south (Edo and Delta), and two states in the west (Ondo and Ekiti) has been investigated in this paper. The major issues amongst others are overloading of transformers, inadequate funding, and vandalisation of Power Holding Company of Nigeria (PHCN) equipments. These shortcomings are also experience by other power distribution companies in other geopolitical zones of Nigeria.

Some valuable recommendations to restore the issues and challenges in the BEDC in particular and other distribution companies in general may be; improving the tariff structure, encouragement of customers to pay bill by using pre-paid meters, increase the number of distribution transformers and transmission substations to avoiding overloading, upgrading or reconstruction of $132 \mathrm{kV}$ lines in the zone to avoid load shedding, etc.

\section{References}

Happ, H., "Cost of Wheeling Methodologies," IEEE Transactions on Power Systems, Vol. 9, No. 1, pp. 147-156, February 1994.

Ilic, M., et al., "Toward Regional Transmission Provision and its Pricing in New England." Utility Policy, Vol. 6, No. 3, pp. 245-256, 1997,

Park, Y., Park, JM Urn, J., and Won, J., "An Analytical Approach for Transmission Costs Allocation in Transmission System," IEEE Transactions on Power Systems, Vol. 13, No, 4, pp. 1407-1412, November 1998,

Power Holding Company Annual Report (2009-2012)

Silva, E., Mesa, S., and Morozowski, M. "Transmission Access Pricing to Wheeling Transactions: A Reliability Based Approach," IEEE Transactions on Power Systems, Vol. 13, No, 4, pp. 1451-1486, November 1998 